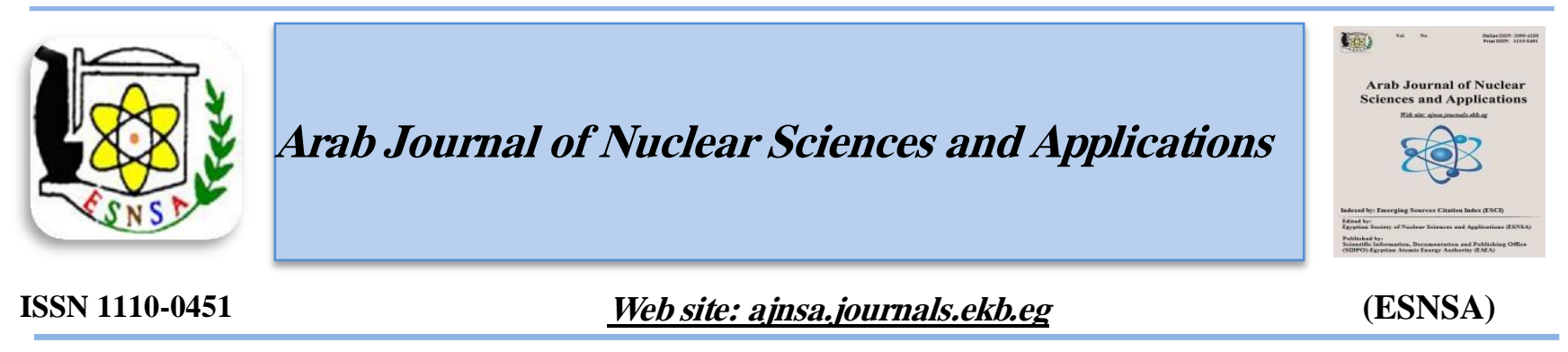

\title{
Measurements of Entrance Skin Dose in Egyptian Pediatric During Diagnostic X-Rays using Thermo Luminescence Dosimeter (TLD -100)
}

\author{
Talaat Salah El din Ahmed \\ Radiation Protection \& Civil Defense Dept., Nuclear Research Center, \\ Egyptian Atomic Energy Authority, Cairo, Egypt
}

Received $7^{\text {th }}$ Feb. 2018 Accepted 27 ${ }^{\text {th }}$ March 2018

\begin{abstract}
Radiation protection in pediatric radiology deserves special attention due to the fact that children are more sensitive to radiation than the adults. This study is concerned with the measurements of pediatric entrance surface dose (ESD) using thermo-luminance dosimeter (TLD, LIF100) for patients ranging from age intervals: 0.1-5 years, 5-10 years and 10-16 years, respectively. A central public pediatric hospital and 120 Egyptian patients were included in this investigation. By careful selection of the patients, three types of simple radiography were selected, as follows: (50 to the chest, 35 to the abdomen and 35 to the skull). Pediatric chest examinations are the most frequent radiological examinations. Comparisons were performed between these doses and the diagnostic reference levels (DRLs).
\end{abstract}

The results showed that mean patient skin doses measured with TLD for the patients ranging from 10-16 years old were $0.20 \mathrm{mGy} 14 \%, 1.10 \mathrm{mGy} 23 \%$ and $1.00 \mathrm{mGy} 40 \%$ for chest, abdomen and skull examination, respectively. The mean ESD values were found to be within the range of ESD reference values, except those for the chest examination.

\section{Introduction}

The medical use of the ionizing radiation represents the major cause of human exposure to artificial ionizing radiation sources $[1,2]$. The development of new techniques and equipment can contribute to an early and accurate diagnosis. However, the dissemination of the application of ionizing radiation in medicine results in the increasing of the human exposure to ionizing radiation. Thus, the medical routine optimization is essential to guarantee the benefits of this technology and to reduce the associated risks. In this way, quality control programs are indispensable.

Entrance skin dose measurement is an important tool in quality control programs: the more optimized the technical procedure, the lower the dose levels [3-5]. The entrance skin dose (ESD) can be influenced by several factors, such as exposure parameters (voltage, exposure time and focus-film distance), field size and $x$-ray beam limitation [6]. To establish entrance skin dose levels, both direct (ionization chambers or solid state dosimeters) or indirect measurements can be utilized. Most of entrance skin dose measurements are performed using Thermo Luminescent Dosimeters (TLD), this type of dosimeters presents some advantageous characteristics such as linearity of response in a wide dose interval, high sensitivity and easy handling.

A commonly utilized Thermo Luminescent (TL) material to measure the entrance skin dose in conventional radiology is the lithium fluoride (LiF: $\mathrm{Mg}, \mathrm{Ti}$ ) because its effective atomic number is very close to the one of human tissue [7].

Corresponding author:talaatsalah2002@yahoo.com

DOI: 10.21608/ajnsa.2018.2643.1056

(C) Scientific Information, Documentation and Publishing Office (SIDPO)-EAEA 


\section{Materials and Methods}

In this work, - the TL material used was LiF: Mg, $\mathrm{Ti}$, produced by Bicron-Harshaw, USA. The LiF: Mg, Ti (TLD-100) - card contains two TLD-100 chips mounted Teflon sheet on aluminum substrates. The TLD system was calibrated to determine the reader calibration factor that is used in evaluating the ESD.

A Harshaw 6000 - plus - readout system was utilized for TL measurements. The TLD cards were treated for $5 \mathrm{~s}$ at a preheat temperature of 150 ${ }^{\circ} \mathrm{C}$ with a heating rate of $15^{\circ} \mathrm{C} / \mathrm{s}$, up to a maximum temperature of $300{ }^{\circ} \mathrm{C}$ within a reading time of 13.3s. The TLD chips were labeled with identification numbers and then fixed in the central position of the beam.

The TLDs were irradiated with radiodiagnostic standard beams (see Table 1) [8] using gamma rays beams with different energies, namely ${ }^{137} \mathrm{Cs}$ of $0.66 \mathrm{MeV}$ and ${ }^{60} \mathrm{Co}$ of $1.25 \mathrm{MeV}$ effective energy. The main dosimetric characteristics of the tested materials (reproducibility, linearity of TL response as a function of the absorbed dose, and energy dependence of TL materials) were determined.

Table (1): $\mathrm{X}$ ray radiation standard qualities utilized in this work [8]

\begin{tabular}{|c|c|c|c|c|}
\hline $\begin{array}{c}\text { Radiation } \\
\text { Quality }\end{array}$ & $\begin{array}{c}{ }^{\text {Ind }} \text { HVL }^{(a)} \\
(\mathbf{m m A l})\end{array}$ & $\begin{array}{c}{ }^{2 n d} \text { HVL } \\
(\mathbf{m m A l})\end{array}$ & $\begin{array}{c}\text { Effective } \\
\text { Energy }(\mathbf{k e V})\end{array}$ & $\begin{array}{c}\text { Air Kerma Rate } \\
(\mathrm{mGy} / \mathrm{min})\end{array}$ \\
\hline RQR2 & 1.43 & 1.84 & 25.0 & 10.82 \\
\hline RQR3 & 1.79 & 2.34 & 27.2 & 19.40 \\
\hline RQR4 & 2.08 & 2.75 & 28.8 & 29.40 \\
\hline RQR5 & 2.32 & 3.39 & 30.0 & 39.86 \\
\hline RQR6 & 2.60 & 3.96 & 31.4 & 51.30 \\
\hline RQR7 & 2.87 & 4.55 & 32.7 & 64.07 \\
\hline RQR8 & 3.17 & 5.11 & 34.1 & 76.81 \\
\hline RQR9 & 3.74 & 6.25 & 36.6 & 104.86 \\
\hline RQR10 & 4.59 & 7.82 & 40.2 & 152.26 \\
\hline
\end{tabular}

(a) The half value layer (HVL) corresponds to the thickness of material that reduces the initial intensity of the radiation beam to half

Table (2): Listing of Reference Levels[9] (pediatric radiographs values are ESD in $\mu \mathrm{Gy}$ )

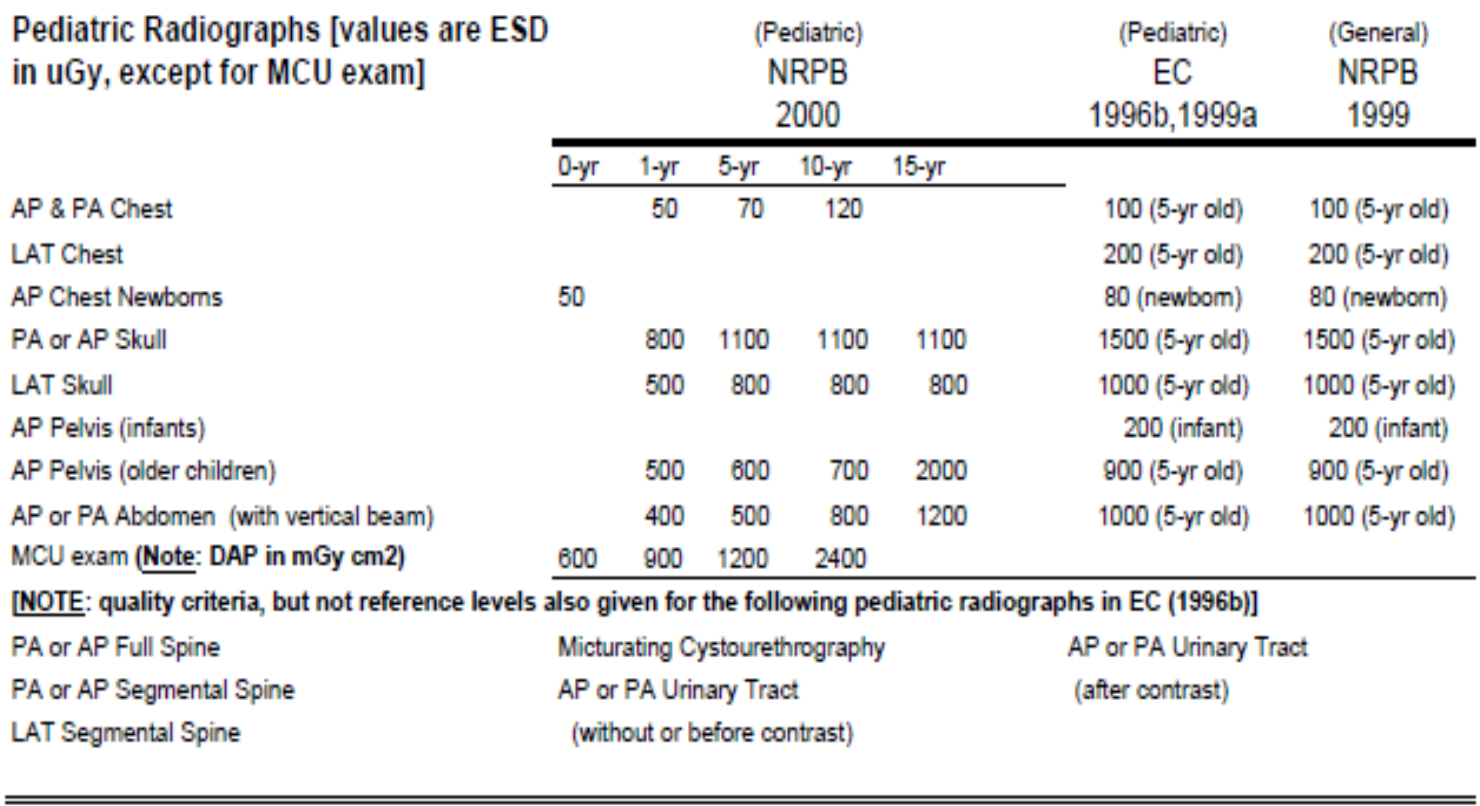




\section{Results and Discussion}

\section{Reproducibility}

The response reproducibility of the TL materials (TLD-100) was evaluated after five identical cycles of irradiation, reading and thermal treatment. The samples were exposed to the ${ }^{137} \mathrm{Cs}$ gamma radiation standard source, at $1 \mathrm{~m}$, with 5 mGy (absorbed dose). The TL response spread of each sample was less $4.5 \%$ for the TLD-100 chips.

\section{Calibration curves}

The TL responses as a function of absorbed dose in air were obtained using all three radiation sources already cited: ${ }^{137} \mathrm{Cs}$ and ${ }^{60} \mathrm{Co}$ gamma sources and $\mathrm{x}$-ray units at the standard radiation qualities listed in Table (1). Because of the low air kerma rate, the samples were irradiated in the ${ }^{60} \mathrm{Co}$ source in an absorbed dose interval of 0.5-10 mGy. In all other cases, the TL materials were irradiated in the absorbed dose interval from 1 to $50 \mathrm{mGy}$. Up to these doses, no saturation of TL response was observed, as shown in Figure (1).

The TL materials exhibited a linear relationship between the TL response and the absorbed dose, as expressed by the correlation coefficients obtained for the applied linear fit. These results showed the feasibility of both materials for the dosimetry of patient in common $\mathrm{x}$-ray examinations.

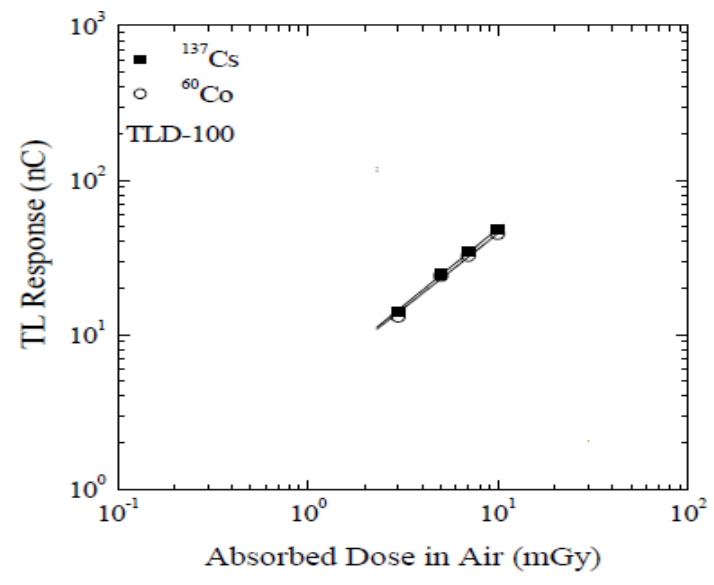

Figure (1): Calibration curves obtained for TLD-100 samples at ${ }^{137} \mathrm{Cs}$ and ${ }^{60} \mathrm{C}$
The TL response as a function of the radiation beam energy was obtained by irradiating the samples with the $\mathrm{x}$-ray qualities listed in Table 1 and the ${ }^{137} \mathrm{Cs}$ standard source, considering the same geometrical conditions, with an absorbed dose in air of $50 \mathrm{mGy}$. The results are shown in Figure (2).

The maximum ratio between the TL response obtained for each tested X-ray quality and the TL response obtained for the ${ }^{137} \mathrm{Cs}$ energy was equal to 1.4 for the TLD-100 samples. These values indicate that even though these materials can be utilized for ESD measurements, correction factors should be used to avoid overestimation of the measured doses.

The mean entrance surface dose for the most common x-ray examinations of different pediatric age groups are summarized in Tables ( 2 to 5 ).

\section{Experimental TLD Results}

The experimental results for ESD obtained using TLD -100 dosimeters are shown in Tables (3 to 6), for the considered age ranges. Furthermore, the comparison of the obtained results with the reference levels is also presented see Table (7).

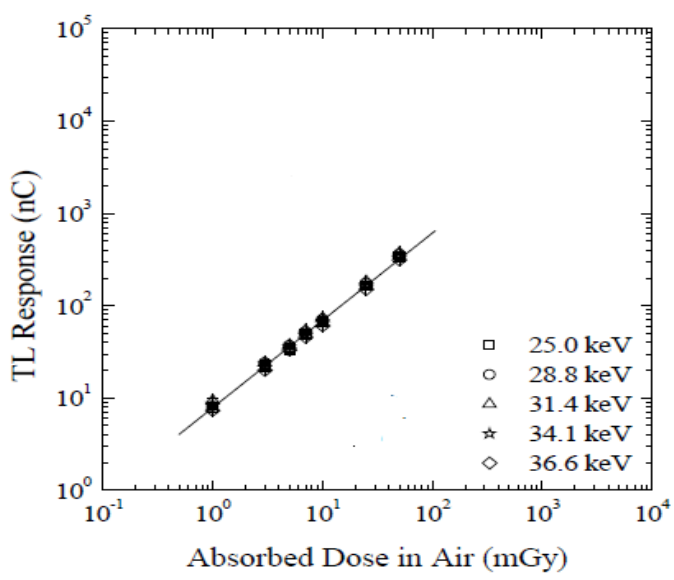

Figure (2): X Ray Energy dependence of TLD-100 sample

Table (2): Technical parameters used to perform radiographic studies and measured ESD in this work (age $<1$ year)

\begin{tabular}{|l|c|c|c|c|c|c|}
\hline \multicolumn{1}{|c|}{ Examination } & $\begin{array}{c}* \text { Distance } \\
(\mathbf{c m})\end{array}$ & $\begin{array}{c}\text { Voltage } \\
\left(\mathbf{k V}_{\mathbf{p}}\right)\end{array}$ & $\begin{array}{c}\text { Current } \\
(\mathbf{m A})\end{array}$ & $\begin{array}{c}\text { mAs } \\
\text { Product }\end{array}$ & Mass $(\mathbf{K g})$ & ESD $(\mu \mathrm{Gy})$ \\
\hline Chest & $\mathbf{1 5 0}$ & $\mathbf{4 8}$ & $\mathbf{1 5 0}$ & $\mathbf{0 . 0 4}$ & \multirow{2}{*}{$\mathbf{3 - 6}$} & $\mathbf{4 0}$ \\
\hline Abdomen & 120 & 54 & 150 & 0.05 & & 210 \\
\hline Skull & 120 & 48 & 150 & 0.08 & & 52 \\
\hline
\end{tabular}

*Focus to Phantom Surface Distance $(\mathrm{cm})$ and the field size $(9 \times 9 \mathrm{~cm})$ 
Table (3): Technical parameters used to perform radiographic studies and measured ESD in this work (age 1 - 5 year)

\begin{tabular}{|c|c|c|c|c|c|c|}
\hline Examination & $\begin{array}{c}\text { *Distance } \\
(\mathbf{c m})\end{array}$ & $\begin{array}{c}\text { Voltage } \\
\left(\mathbf{k} V_{\mathrm{p}}\right)\end{array}$ & $\begin{array}{c}\text { Current } \\
(\mathbf{m A})\end{array}$ & $\begin{array}{c}\mathrm{mAs} \\
\text { Product }\end{array}$ & Mass (Kg) & $\mathrm{ESD}(\mu \mathrm{Gy})$ \\
\hline Chest & 150 & 55 & 150 & 0.04 & \multirow{3}{*}{$6-16$} & 51 \\
\hline Abdomen & 120 & 50 & 150 & 0.10 & & 200 \\
\hline Skull & 120 & 58 & 150 & 0.15 & & 200 \\
\hline
\end{tabular}

*Focus to Phantom Surface Distance $(\mathrm{cm})$ and the field size $(10 \times 10 \mathrm{~cm})$

Table (4): Technical parameters used to perform radiographic studies and measured ESD in this work (age 5 - 10 year)

\begin{tabular}{|l|c|c|c|c|c|c|}
\hline Examination & $\begin{array}{c}\text { *Distance } \\
(\mathbf{c m})\end{array}$ & $\begin{array}{c}\text { Voltage } \\
(\mathbf{k V})\end{array}$ & $\begin{array}{c}\text { Current } \\
(\mathbf{m A})\end{array}$ & $\begin{array}{c}\text { mAs } \\
\text { Product }\end{array}$ & Mass (Kg) & ESD $(\mu \mathrm{Gy})$ \\
\hline Chest & $\mathbf{1 5 0}$ & $\mathbf{4 6}$ & $\mathbf{1 5 0}$ & $\mathbf{0 . 0 6}$ & & $\mathbf{1 0 0}$ \\
\hline Abdomen & 120 & 55 & 150 & 0.20 & $\mathbf{1 5}-\mathbf{2 9}$ & 400 \\
\cline { 1 - 4 } Skull & 120 & 60 & 150 & 0.20 & & 920 \\
\hline
\end{tabular}

*Focus to Phantom Surface Distance $(\mathrm{cm})$ and the field size $(10 \times 10 \mathrm{~cm})$

Table (5): Technical parameters used to perform radiographic studies and measured ESD in this work (age 10 - 15 year)

\begin{tabular}{|l|c|c|c|c|c|c|}
\hline \multicolumn{1}{|c|}{ Examination } & $\begin{array}{c}\text { *Distance } \\
(\mathbf{c m})\end{array}$ & $\begin{array}{c}\text { Voltage } \\
(\mathbf{k V})\end{array}$ & $\begin{array}{c}\text { Current } \\
(\mathbf{m A})\end{array}$ & $\begin{array}{c}\text { mAs } \\
\text { Product }\end{array}$ & Mass (Kg) & ESD ( $\mu$ Gy) \\
\hline Chest & $\mathbf{1 5 0}$ & $\mathbf{5 8}$ & $\mathbf{1 5 0}$ & $\mathbf{0 . 1 5}$ & \multirow{2}{*}{$\mathbf{2 0 - 4 5}$} & $\mathbf{4 0 0}$ \\
\hline Abdomen & 120 & 60 & 150 & 0.30 & 1100 \\
\hline Skull & 120 & 66 & 150 & 0.25 & & 1300 \\
\hline
\end{tabular}

*Focus to Phantom Surface Distance $(\mathrm{cm})$ and the field size $(12 \times 12 \mathrm{~cm})$

Table (7): Comparison of Egyptian Pediatric Radiographs of Entrance Skin Dose with international reference values

\begin{tabular}{|l|c|c|c|}
\hline Examination & $\begin{array}{c}* \text { E.C } \\
\text { Average ESD } \\
\text { (mGy) } \\
(5-\text { yr old })\end{array}$ & $\begin{array}{c}* * \text { NRPB } \\
\text { Average ESD (mGy) } \\
\text { Age group }(0.1-15 \text { year) }\end{array}$ & $\begin{array}{c}\text { Egyptian Present work } \\
\text { Average ESD (mGy) } \\
\text { Age group }(0.1-15 y e a r)\end{array}$ \\
\hline Chest & $\mathbf{0 . 2 0 0}$ & $\mathbf{0 . 0 5 0 - 0 . 1 2 0}$ & $\mathbf{0 . 0 4 0}-\mathbf{0 . 4 0 0}$ \\
\hline Abdomen & $\mathbf{1 . 0 0 0}$ & $\mathbf{0 . 4 0 0 - 1 . 2 0 0}$ & $\mathbf{0 . 2 0 0 - 1 . 1 0 0}$ \\
\hline Skull & $\mathbf{1 . 5 0 0}$ & $\mathbf{0 . 8 0 0 - 1 . 1 0 0}$ & $\mathbf{0 . 5 0 0 - 1 . 3 0 0}$ \\
\hline
\end{tabular}

*European Communities 1996b,1999a REF (9)

**National Radiological Protection Board (November 2000) REF(9)

\section{Conclusions}

Thermo Luminescence dosimeters LiF: Mg, Ti (TLD-100) showed an adequate performance for entrance skin dose measurements in conventional radiographic procedures. However, the knowledge about the beam energy is essential for the conversion from the TL response to the appropriate dosimetric quantity, avoiding overestimation of ESD values.

The following mean Entrance Skin Dose (ESD) has been obtained for:
- Skull-from 0.06 to $1.30 \mathrm{~m}-\mathrm{Gy}$ (with ESD mean value of $1.10 \mathrm{~m} \mathrm{~Gy} \pm 19 \%$ )

- Abdomen - from 0.20 to $1.10 \mathrm{~m}$ - Gy (with ESD mean value of $1.00 \mathrm{mGy} \pm 15$ $\%$ )

- Chest - from 0.05 to $0.40 \mathrm{~m}$ - Gy (with ESD mean value of $0.20 \mathrm{mGy} \pm 15 \%$ )

The mean ESD values were found to be within the range of ESD reference values, except those obtained for the chest examination. 


\section{References}

1- BERRINGTON DE GONZALEZ A., DARBY S., Risk of cancer from diagnostic X-rays: estimates for the UK and 14 other countries, Lancet 363 (2004) 345.

2- COVENS P., BERUS, D., BULS, N., et al., Personal dose monitoring in hospitals: Global assessment, critical applications and future needs. Radiat. Prot. Dosim. 124 (2007) 250.

3- COMPAGNONE, G., PAGAN, L., BERGAMINI, C., Local diagnostic reference levels in standard $\mathrm{X}$ ray examinations. Radiat. Prot. Dosim. 113 (2005) 54.

4- TUNG, C.J., TSAI, H.Y., LO, S.H., et al., Determination of guidance levels of dose for diagnostic radiography in Taiwan. Medical Phys. 28 (2001) 850.

5- ORGANISMO INTERNATIONAL DE ENERGIA ATOMICA, Normas Básicas Internationales de Seguridad para la Protección contra la Radiación Ionizante y para la Seguridad de las Fuentes de
Radiación, Colección Seguridad No. 115, Vienna (1997).

6- OLIVEIRA, M.L., KHOURY, H., Influência do procedimento radiográfico na dose de entrada na pele de pacientes em raios-X pediátricos, Radiol. Bras. 36 (2003) 105.

7- PORTAL, G., Review of the principal materials available for thermoluminescent dosimetry. Radiat. Prot. Dosim. 17 (1986) 351.

8- INTERNATIONAL ELECTROTECHNICAL COMMISSION, Medical diagnostic X-ray equipment - Radiation conditions for use in determination of characteristics, IEC 61267, Geneva (2005).

9- IAEA (2001). International Conference (IAEA/EC/PAHO/WHO). Developing and Using Dose Guidance (Reference) Levels in Radiology and Nuclear Medicine Examinations. Contributed papers, pages 403-487, in Radiological Protection of Patients in Diagnostic and Interventional Radiology, Nuclear Medicine and Radiotherapy (International Atomic Energy Agency, Vienna). 